\title{
THEORETICAL AND METHODOLOGICAL APPROACHES TO DEFINING THE SUBJECT OF THE METHODS OF TEACHING HUMANITARIAN DISCIPLINES AT HIGHER SCHOOL (AS EXAMPLIFIED BY THE MULTICULTURAL EDUCATIONAL MODEL)
}

\section{Nediukha M. P.}

\section{INTRODUCTION}

The search by modern university science for ways of establishing the multicultural educational model is associated, as it is known, with established paradigms of scientific knowledge - classical, non-classical and post-non-classical ones, a new worldview in the unity of its natural, social and cosmic bases. It is evident that there is a need for synthesis of theoretical and methodological research attitudes that would overcome the cognitive, heuristic limitations of traditional, established approaches through the latest, non-traditional ones, which allows, in particular, to substantiate the subject of the methods of teaching humanities in higher education in accordance with the requirements of the multicultural educational model as the process of teaching and learning that is based on democratic values, contributes to the development of cultural pluralism in the multicultural, interdependent world ${ }^{1}$, promotes the movement toward goals and ideals, which are not achievable in full ${ }^{2}$. We are talking about the possibilities of combining in the educational process two crucial educational and cultural traditions - the natural sciences one and the humanities one with the prospect of a possible synthesis of the fundamental laws of nature and space, society and man in the globalized socio-cultural space.

1. The curr ent state of scientific development of the problems of studying the methods of teaching humanitarian disciplines and its subject

The issues of the content of the educational process, its construction, the structure of the course of academic disciplines are actively discussed in scientific and methodical literature; they find both theoretical

\footnotetext{
${ }^{1}$ Bennett C. I. Comprehensive multicultural education: Theory and practice / C.I. Bennett. Boston: Allyn \& Bacon, 1999. - 345 p.

${ }^{2}$ Banks J. A. Multicultural Education: Characteristics and Goals / J.A. Banks // Multicultural Education: Issues and Perspectives. Wileys \& Sons, 2003. - P. 3-31.
} 
development and implementation in the practice of the educational process of higher education. The specified area of scientific research is necessarily promoted by the clearness of the scientific community about understanding the object of studying the methods of teaching as a learning process ${ }^{3}$ or a pedagogical process ${ }^{4}$. Dialogue between representatives of different intellectual and cultural traditions ${ }^{5}$, creative discussions ${ }^{6}$, critical thinking ${ }^{7}$, being components of the multicultural educational model, contribute to reducing the gap between science and education, deepen understanding the content of academic disciplines ${ }^{8}$, organizational forms and methods of learning ${ }^{9}$, new information and communication technologies in the system of higher education ${ }^{10}$, the place, role and purpose of electronic textbooks and teaching aids in the educational process $^{11}$, draw attention to research that embodies modern trends of educational change ${ }^{12}$, the dynamics of modernization of the educational process ${ }^{13}$, ways of approaching the European educational

3 Нелеп А. Т. Теоретические проблемы методики преподавания философии. Киев: «Вища школа», 1973. - С. 19.

4 Мойсеюк Н. С. Педагогіка : навчальний посібник. Вид. п’яте, доп. і перероб. Київ: ВАТ «Білоцерківська книжкова фабрика», 2007. С. 256.

5 Андрущенко Т.В. Ціннісний дискурс цивілізацій: монографія. Київ: Університет «Україна», 2011. $-440 \mathrm{c}$.

6 Дмитренко М. А. Наука і освіта як невід'ємна складова механізму реалізації стратегій інноваційного розвитку суспільства // Науковий часопис НПУ імені М. П. Драгоманова. Серія 22. Політичні науки та методика викладання соціально-політичних дисциплін. 2009. Випуск 2. - С. $24-33$.

7 Недюха М. П. Критика як теоретико-пізнавальний та діалогово-полемічний конструкт конституційно-правового мислення // II Всеукраїнські правові наукові читання пам'яті доктора юридичних наук, професора, заслуженого юриста України, член-кореспондента Національної академії правових наук України Ніни Романівни Нижник: збірник матеріалів / за заг. ред. А. Є. Шевченка. Вінниця: ТОВ «ТВОРИ», 2018. 180 с. - С. 94-98.

${ }^{8}$ Бех В. П., Бех Ю. В. У пошуках нової парадигми освіти // Нова парадигма. Філософія. Політологія. Соціологія / Нац. пед. ун-т імені М. П. Драгоманова. Київ: Вид-во НПУ імені М. П. Драгоманова, 2014. Вип. 123. - С. 19-32.

9 Мельниченко О. П. Основні методи та форми навчання в сучасній вищій школі // Науковий часопис Національного педагогічного університету імені М. П. Драгоманова. Серія 5. Педагогічні науки: реалії та перспективи. Випуск 27. 2011. - С. 176-180.

10 Кліпа Ю. В. Сучасні основи навчання студентів засобами on-line в вищій школі // Нові концепції викладання у світлі інноваційних досягнень європейської дидактики вищої школи : матеріали міжн. наук.-метод. конф., 30-31 жовтня 2017 р. / Укл. С. М. Іваненко та ін. Київ: Вид-во НПУ імені М. П. Драгоманова, 2017. - С. 260-262.

${ }_{11}$ Булда А. А. Електронний підручник в системі сучасних засобів навчання // Науковий часопис Національного педагогічного університету імені М. П. Драгоманова. Серія 22. Політичні науки та методика викладання соціально-політичних дисциплін : зб. наук. праць. Київ: Вид-во НПУ імені М. П. Драгоманова, 2009. Випуск 1. - С. 18-21.

12 Горбунова Людмила, Зглінська Наталія, Пролеєв Сергій та ін. Трансгуманітарність як чинник розвитку сучасної науки і освіти // Філософія освіти: наук. часопис. 2011. № 1-2. / Ін-т вищої освіти АПН України, Нац. пед. ун-т імені М. П. Драгоманова, Укр. академія політичних наук. Київ: Вид-во НПУ імені М.П. Драгоманова, 2011. - С. 97-141.

13 Червона Л. М. Принцип модернізації вітчизняної вищої освіти: академізм vs прагматизм // URL: journals.uran.ua/index.php/2312-1947/article/.../25971. 
standards ${ }^{14}$. Problems of the formation of the student's personality ${ }^{15}$, its value $^{16}$ and ideological ${ }^{17}$ preferences are actively discussed. Instead, questions of the methods of teaching humanities are covered mainly from the perspective of: a) the theoretical and methodological potential of different paradigms of scientific knowledge - of the actionalist intellectual tradition $^{18}$, polyparadigmal principles ${ }^{19}$, synergetics ${ }^{20}$; b) trends ${ }^{21}$ and strategies $^{22}$ for the transformation of Ukrainian education; c) organic combination of traditional and advanced learning technologies ${ }^{23}$; d) step by step nature of the formation of knowledge, skills and abilities ${ }^{24}$; e) intercurricular and interpersonal relations ${ }^{25}$; e) the quality of the educational process ${ }^{26}$, etc. The importance of taking into account by

14 Тараненко Г. Г. Євроінтеграційні перспективи України на сучасному етапі // Науковий часопис Національного педагогічного університету імені М. П. Драгоманова. Серія 22. Політичні науки та методика викладання соціально-політичних дисциплін: зб. наук. праць. Випуск 21. Київ: Вид-во НПУ імені М. П. Драгоманова, 2017. - С. 95-100.

${ }^{15}$ Скотна Надія. Філософська проблема особистості в цивілізаційному вимірі // Молодь і ринок. Дрогобич : 2015. № 3 (122). - С. 6-14.

16 Морозов В. В. Фундаментальні цінності як засада організації освіти в європейському просторі // Науковий часопис Національного педагогічного університету імені М. П. Драгоманова. Серія 7: Релігієзнавство. Культурологія. Філософія / ред. рада: В. П. Андрущенко (голова). Вип. 29 (41). Київ: Вид-во НПУ імені М. П. Драгоманова, 2013. - С. 263-272.

17 Литвиненко Т. С. Філософія виховання у трансформаційному освітньому просторі // Науковий часопис Національного педагогічного університету імені М. П. Драгоманова. Серія 7: Релігієзнавство. Культурологія. Філософія / ред. рада: В. П. Андрущенко (голова). Вип. 37 (50). Київ: Вид-во НПУ імені М. П. Драгоманова, 2017. - С. $76-84$.

${ }^{18}$ Гавриленко І. М., Мельник П. В., Недюха М. П. Соціальний розвиток : навчальний посібник. Київ: Академія ДПС України, 2001. С 128-169, 424-468.

19 Терепищий С. О. Філософська парадигма сучасних освітніх ландшафтів : автореферат дис. ... докт. філос. наук : 09.00.10 / М-во освіти і науки України, Нац. пед. ун-т ім. М. П. Драгоманова. Київ, 2016. 34 с.

${ }^{20}$ Синергетика в образовании : возможности методологии (круглый стол в редакции журнала “Філософія освіти” / Філософія освіти. Philosophy of Education: науковий журнал. 2006. № 3(5) // Ін-т вищої освіти НАПН України, Нац. пед. ун-т імені М. П. Драгоманова, 2006. - С. 54-91.

${ }^{21}$ Регейло I. Ю. Тенденції підготовки наукових і науково-педагогічних кадрів вищої кваліфікації в Україні у XX - на початку XXI століття : автореферат дис. ... докт. пед. наук : 13.00 .04 / М-во освіти і науки України, Нац. пед. ун-т імені М. П. Драгоманова. Київ: 2015. 39 с.

22 Чижова О. М. Стратегія трансформації української освіти в контексті розуміння прагматизму // Науковий часопис Національного педагогічного університету імені М. П. Драгоманова. Серія 22: Політичні науки та методика викладання соціально-політичних дисциплін : зб. наук. праць. Випуск 15. Київ: Вид-во НПУ імені М. П. Драгоманова, 2014. - С. 190 -195.

23 Без'язичний Б. І., Журід С. М., Худякова В. Б., Шаленко В. В. Технологічний підхід до освітнього процесу у ВНЗ // Науковий часопис Національного педагогічного університету імені М. П. Драгоманова. Серія 15. Випуск 5 (87). Київ: Вид-во НПУ імені М.П. Драгоманова, 2017. С. 9-12.

${ }^{24}$ Концептуальні засади розвитку педагогічної освіти в Україні та її інтеграції в європейський освітній простір // URL: www.mon.gov.ua/images/ education.

${ }^{25}$ Клепко С. Ф. Автономія університету і міждисциплінарна інтеграція // Магістратура: історія становлення, перспективи розвитку: матеріали регіональної наук.- практ. конф., 21 квітня 2004 р. / Полтавський державний педагогічний університет імені В. Г. Короленка, Полтавський обласний інститут післядипломної педагогічної освіти імені М. В. Остроградського. Полтава: АСMI, 2004. C. 40-44.

${ }^{26}$ Кремень В. Г. Проблеми якості української освіти в контексті сучасних цивілізаційних змін // Європейські педагогічні студії / Асоціація ректорів педагогічних університетів Європи; ред. кол. В. П. Андрущенко (голова) [та ін.]. Вип. 5-6. Київ: Вид-во НПУ імені М. П. Драгоманова, 2015. C. $12-21$. 
the methods of teaching humanitarian disciplines the possibilities of institutional counteraction to corruption in Ukraine ${ }^{27}$, Ukrainian-Russian relations in the context of the war of identities ${ }^{28}$, the challenges and threats of globalization ${ }^{29}$, its impact on the national cultural identity ${ }^{30}$ and the system of education in general ${ }^{31}$ is also emphasized. Participants of the educational process expressed appreciation to workshops in various areas of legal knowledge, in particular international law with regard to the study of the European experience in harmonizing interstate relations, strengthening the status of supranational institutions, securing the rule of law, and creating a new world order ${ }^{32}$. Numerous works of Ukrainian and foreign scholars cover foreign educational experience ${ }^{33}$, the theory and practice of organizing and securing the college educational process ${ }^{34}$ including criteria, standards and methods for assessing teachers' teaching competence $^{35}$, provision of educational services ${ }^{36}$, etc.

However, despite the obvious progress in many areas of the implementation of the educational process in higher education, the scientific and methodological substantiation of the structure of courses in humanities, in particular sociology, political science, and legal science,

${ }^{27}$ Подоляка С. А. Теоретико-практичні основи адміністративно-правового забезпечення протидії корупції в органах прокуратури України : монографія. Київ: «Людмила», 2018. 440 с.

28 Перепелиця Г. М. Україна - Росія: війна в умовах співіснування. Київ: Видавничий дім «Стилос», 2015. 880 с.

29 Горбунова Людмила. Транскультурна освітня стратегія в контексті викликів глобалізації // Філософія освіти. Philosophy of Education : науковий журнал. 2014. № 1 (14) / Ін-т вищої освіти НАПН України, Нац. пед. ун-т імені М. П. Драгоманова, 2014. С. 158-198.

30 Шевель Н. О. Формування української національної ідентичності в умовах глобалізації освіти // Науковий часопис НПУ імені М. П. Драгоманова. Серія 22. Політичні науки та методика викладання соціально-політичних дисциплін : [збірник наукових праць]. Київ: Видавництво НПУ імені М. П. Драгоманова, 2014. Спецвипуск : Політика і духовність в умовах глобальних викликів : матеріали Міжнар. наук.-практ. конференції, 2-3 квітня 2014 р. - С. 338-342.

${ }^{31}$ Горбунова Людмила. Транскультурна компетентність: освітній шлях до глобальної культури миру // Філософія освіти. Philosophy of Education : науковий журнал. 2014. № 2 (15) / Ін-т вищої освіти НАПН України, Нац. пед. ун-т імені М.П. Драгоманова, 2014. - С. 141-167.

32 Тимченко Л. А., Тимченко Л. Д. Международное право : практикум. Ирпень: Академия ГНС Украины, 2002. 290 с.

33 Штобрин Славомір. Становище філософії освіти в Польщі в кінці XX - на початку XXI століття // Філософія освіти. Philosophy of Education : науковий журнал. 2015. № 1 (16) / Ін-т вищої освіти НАПН України, Нац. пед. ун-т імені М.П. Драгоманова, 2015. - С. 140 -156.

${ }^{34}$ Banks J. A. Cultural Diversity and Education: Foundations, Curriculum and Teaching . - 2014. (6th ed.). Boston: Allyn \& Bacon. 384 pp.

${ }^{35}$ Кляп М. І. Підвищення педагогічної майстерності викладача ВНЗ у контексті інтернаціоналізації вищої школи України // Науковий часопис Національного педагогічного університету імені М. П. Драгоманова. Серія 16 : збірник наукових праць. Вип. 25 (35). Київ: Вид-во НПУ імені М. П. Драгоманова, 2015. - С. 47-52.

${ }^{36}$ Біляєва I. I. Медіа-освіта як ціннісно-культурний компонент трансформації сучасного суспільства // Науковий часопис НПУ імені М. П. Драгоманова. Серія 22. Політичні науки та методика викладання соціально-політичних дисциплін : [збірник наукових праць]. Київ: Видавництво НПУ імені М. П. Драгоманова, 2014. Спецвипуск : Політика і духовність в умовах глобальних викликів : матеріали Міжнар. наук.-практ. конференції, 2-3 квітня 2014 р. - С. 280-288. 
has not yet been proposed. Although as early as at the end of the last century, the importance of solving educational and methodological problems associated with the threats of the fragmentation of scientific knowledge and lack of unity of its elements was rightly emphasized; this fragmentation is evidenced, in particular, by curricula and manuals, where a presentation of special sociological theories (branch sociologies), but not the general theory is often given ${ }^{37}$.

In scientific and methodical literature, the main focus is usually on the development of specific recommendations, tools, techniques, forms of education and training, generalization of teaching experience based on the need to reform the content of education, and there is lack of coverage of problems of the relationship of methodology and methods, of the determining role of the former in relation to the latter, of the problem of "what to teach?" students at lectures and practical classes, during their independent work, etc. Undoubtedly, the development of private methodological issues (the methods for lecturing, conducting seminars, tests, examinations, the technologization and computerization of teaching, the introduction of continuous, distance, on-line education, etc.) is an important and necessary thing. However, the development of problems of subject comprehension of the content of a discipline requires, at least, the conduct of general theoretical, interdisciplinary research with regard to, in particular, the content filling of the educational process in higher education, the definition of its theoretical and methodological foundations, the general "strategy" of training and its components.

\section{The methods of teaching humanities as a didactically redesigned system of scientific knowledge}

It is well-known that the subject of a science is the laws of the development of a particular sphere, an aspect of social life, the level of their comprehension and turning into corresponding theories, doctrines, etc. For example, sociology, as claimed by Pitirim Sorokin, is "a science that studies the lives and activities of people living in a society of ones of their kind and the results of such joint activities" ${ }^{38}$.

An academic discipline reflects the same subject as the science, but indirectly: through the content and level of development of the actual science. The higher a science is developed, the more comprehensively

\footnotetext{
37 Якуба О. О. Соціологія. Харків: «Фоліо», 1996. - С. 9.

${ }^{38}$ Сорокин П. А. Общедоступный учебник социологии. Статьи разных лет / Ин-т социологии. Москва: Наука, 1994. С. 8.
} 
and thoroughly it reflects the subject of its research and, accordingly, the more fully and deeply its essence can be clarified, laid out in curricula, textbooks and manuals, brought to the consciousness of students through the methods of its teaching. Of course, with certain reservations, because a subject matter cannot comprehend all the wealth of the content of the science; it involves only the most significant, generally accepted, established propositions. At the same time, in its problems, it is broader than the science and includes in its structure a number of topics, sections that are not directly related to its subject, its logic, but the study of which is necessary from the training and educational point of view. Into such topics, let us say, in the course of sociology, we can put proto-sociology, the history of sociological thought as well as the definition of the place of the subject matter in the system of professional training of students, ensuring phased nature, interdisciplinary and intercourse ties, etc. Apart from content and structural differences, science and academic discipline also differ in the form of their existence: training courses as a system of knowledge are created through the scientific and methodological processing of the content of a science so that students can comprehend it. One cannot ignore the influence of the laws of pedagogy, the principles of didactics, etc, either. One can consider attributive a certain lag of an academic discipline behind the science in terms of content comprehension of the problems of its subject. Obviously, this requires time, intellectual, personnel and organizational resources, training buildings and the corresponding infrastructure as well as teaching and methodological support (preparation of textbooks, manuals, course programs, etc).

A science and an educational discipline also differ in "departmental" belonging, which determines their different structure, component composition. Whereas the structure of a course belongs to the subject matter, is directly related to the process of learning, the development and education of students, the structure of the science reflects the process of differentiation of knowledge within this particular science, within which there are relatively independent branches of knowledge. In addition, a subject matter should reflect the interdisciplinary connections; take into account the sequence, the place of one or another discipline in the system of training a future specialist, the specifics of the institution of higher education, the department, the specialty in their subordination to the current state of science and the planetary tendencies of its development. Accordingly, it can be argued that an academic discipline in its essence and purpose is a didactically sound system of knowledge in accordance 
with the content of the multicultural model of education ${ }^{39}$, its principles ${ }^{40}$, tasks $^{41}$, goals and objectives ${ }^{42}$.

In addition to optimizing the educational process on the basis of the achievements of modern science, the above-mentioned educational paradigm ${ }^{43}$ involves a person-centered approach, critical thinking, acquiring the appropriate competence, etc., that is, it should be oriented toward the capabilities and needs of future professionals in accordance with the multinational and multicultural environment of their professional activities. And this means that the modern educational paradigm must be open, non-linear, capable of self-organization and self-movement, involve the responsibility of the choice of a teacher in at least two of its main meanings: a) the use of the possibilities of science in its classical, nonclassical and post-non-classical dimensions as a means, resource and potential of socio-cultural changes; b) the construction of an educational subject as an invariant of science, the definition of its structure, the sequence of laying out the content of training in accordance with the specifics of the institution of education, the level of preparation of the students. This is on the one hand. On the other hand, a subject matter should serve as the main means of forming the tolerant principles of their worldview and world comprehension, of forming their professional qualities and personal virtues. From this, it is obvious that the student cannot stand aside from the scenarios of the formation of his own professional and social environment of being and, accordingly, he should be regarded as the object and subject of the educational process at the same time.

\section{Definition of the subject of the methods of teaching humanitarian disciplines as a search research attitude}

In the scientific literature, various search models of the process of substantiation, definition of the subject of the methods of teaching humanitarian disciplines in higher education are offered. Thus, dominant are ideas according to which: 1) the clarification of the essence of the

\footnotetext{
39 Banks J. A. Multicultural Education: Characteristics and Goals / J.A. Banks // Multicultural Education: Issues and Perspectives. Wileys \& Sons, 2003. - P. 3-31.

40 Каньковський Ігор. Принципи професійного навчання фахівців у сучасній вищій школі // Молодь і ринок. Дрогобич : 2015. № 12 (131). С. 15-22.

${ }^{41}$ Jefferson N. Migrant Report Office - Multicultural Education, US Dpt of Education, April, 2002. P. 16-24.

${ }^{42}$ Горак Оксана. Філософія гуманізму. Становлення та розвиток гуманістичної парадигми освіти // Молодь і ринок. Дрогобич, 2015. № 11 (130). С. 147-150.

43 Banks J. A. Multicultural Education: Characteristics and Goals / J.A. Banks // Multicultural Education: Issues and Perspectives. Wileys \& Sons, 2003. - P. 3-31.
} 
subject of the methods of teaching should be carried out through disclosure of the particularities of teaching, which should be determined by the specifics of the subject of a science, its theoretical and methodological potential ${ }^{44}$; 2) the subject of the methods of teaching should be conditioned not by the content of the relevant science, but by the requirements of didactics ${ }^{45}$; 3 ) the methods of teaching humanities represent the science of managing the learning process, which allows its subject to be regarded as a branch of the philosophy of education, in particular, in the cases of information and technological forecasting and management of the development of education in general, the definition of areas for its reforming, the development of state standards of education, the understanding of the ideal of education, the ideal of a harmoniously developed personality ${ }^{46}$; 4 ) the methods of teaching should be considered as a form of comprehension of the content of the science being studied, in accordance with the conditions of life in multicultural society, the prospects for its modernization ${ }^{47}$; 5 ) the subject of the methods of teaching humanities should be determined on the basis of a number of conditions: a) the cognition and use of the laws of pedagogy and didactics; b) the development and application of methods, organizational forms, means, techniques, technologies, etc, which ensure teaching humanities as the basis of world outlook and methodology of knowledge, the formation of a multicultural person; c) the need for humanization of education, which is associated with both objective and subjective reasons, the main among which being the transition of the world community to a new social dimension, which is based on a professionally trained personality in the unity of his national and universal values, humanistic orientations, who, while preserving his own dignity, cultural identity has to adapt to living conditions in the multicultural space ${ }^{48}$.

44 Бех В. П. Философская рефлексия предмета политологии // Вопросы политологии. 2016. № 2 (22). С. 7-16.

45 Лакомчак Зоряна. Дидактичний потенціал сучасної інтернет-дидактики // Молодь і ринок. Дрогобич : 2015. № 8 (127). С. 121-124.

${ }^{46}$ Васиньова Н.С. Розвиток теорії управління вищими навчальними закладами в Україні (остання чверть XX - початок XXI століття). Дисертація на здобуття наук. ступ. канд. пед. наук за спеціальністю 13.00.06 / М-во освіти і науки України, Луганський національний університет імені Тараса Шевченка. Старобільськ : 2019. - 294 с.

${ }^{47}$ Bakhov I. S. Historical dimension to the formation of multicultural education of Canada. Pedagogika. 2015. Vol. 117, Issue 1. P. 7-15.

${ }^{48}$ Недюха М. П. Критика як поняття класичної науки та соціальний феномен громадянського суспільства: потенціал конституційного та міжнародного права // Критичне мислення у вільному суспільстві: теоретико-методологічний, конституційно- та міжнародно-правовий потенціал: Матеріали міжнародної науково-практичної конференції, м. Київ, 17 квітня 2019 р. Київ: Таврійський національний університет імені В. І. Вернадського, 2019. 156 с. 
The last point of view (from the aforementioned ones) deserves, in our opinion, special attention, since the proposed approach to the definition of the subject of the methods of teaching humanitarian disciplines gives the opportunity to rely on all the wealth of the content of the discipline being studied, to build the educational process in accordance with the general civilizational tendencies of socio-cultural changes, the ideals of democracy. The $21^{\text {st }}$ century should be the era of sovereign states with their multicultural and ecological and natural environment, with their spiritual identities, national interests and aspirations. Thus, the humanization of education works for the future and man in it as the creator of the conditions of his everyday life, forms, according to the well-known expression of Polish sociologist Piotr Sztompka, "civilization competence" as the ability to find satisfactory answers to the challenges of the globalized world, to form an atmosphere of tolerance and trust in society, the basis of which is represented by human dignity.

The advantages of the above approach also include the emphasized expediency with regard to the definition of the subject of the methods of teaching humanitarian disciplines, the use of the laws of pedagogy and didactics, effective forms, means, methods and technologies of learning, which are conditioned by the established paradigms of scientific knowledge, by worldview and value vision of the world based on understanding the limitations of purely rational forms of cognition, on the priority of personality oriented education and on the formation of a holistic person as a natural, social and cosmic creature.

The urgent tasks facing the methods of teaching humanities in higher education in accordance with the main propositions of the multicultural model of education are associated with the need for students to master the methodology and specific methods of dialogue, scientific polemics, ability to critically analyze social reality, to find satisfactory answers to the challenges of the present, in particular, the threat of a break-up of the established world order, international terrorism, hybrid wars, etc. Formation of professional competence, professional formation of student youth is inseparable from the creative development of the potential of scientific criticism as a theoreticalcognitive and dialogue-polemical construct of scientific thinking, and hence an integral part of the content of education, methodological and innovativetechnological potential of higher education ${ }^{49}$.

\footnotetext{
49 Недюха М. П. Критика як поняття класичної науки та соціальний феномен громадянського суспільства: потенціал конституційного та міжнародного права // Критичне мислення у вільному суспільстві: теоретико-методологічний, конституційно- та міжнародно-правовий потенціал: Матеріали міжнародної науково-практичної конференції, м. Київ, 17 квітня 2019 р. Київ: Таврійський національний університет імені В. І. Вернадського, 2019. С. 14-20.
} 
It is obvious that the aforementioned activity of subject definition of the essence of the methods of teaching humanities should be based on the paradigmatic conditionality of scientific knowledge in its classical, nonclassical and post-non-classical dimensions, the awareness of the direct connection of knowledge with the relations that form between people in the process of their daily life and the nature, method and features of their legal and regulatory and ethical and moral regulation. It is clear that the specified content and functional orientation of the content of education, the dynamics of the process of training and education should be deployed and subordinated to the main goal - the formation of a civilization (European) identity as a unity of the universal, continental, national and regional. Individualization as, according to Sygmunt Bauman, "the establishment of the autonomy of an individual de jure" ${ }^{50}$, can be considered another embodiment of civilization identity. Scientific, educational and methodological and pedagogical and didactic combination of these requirements in the course of teaching humanitarian disciplines allows to carry out, in accordance with the basic foundations of multicultural education, the didactically correct transformation of a science into the corresponding educational discipline, to ensure the proper sequence, stepping, systemacity and effectiveness of the preparation of the future specialist, obtaining him qualification competence for life in a multicultural environment.

For example, teaching legal disciplines in accordance with the requirements of the principle of unity of the universal, continental, national and regional contributes, as shown by the experience of Vernadsky Taurida National University, to the humanization of understanding, interpretation of national legislation with several meanings: a) the humanization of legislation as the correspondence of its norms, legal and regulatory acts to universal values and moral and ethical principles; b) the humanization of legislation as its harmonization - the process of approximation and adaptation to the legal norms of the member states of the European Union $^{51}$; c) humanization of the legislation as the implementation of the norms of international law in the domestic legislative field; d) humanization of legislation as the interdependent process of interaction between different legal systems with regard to,

\footnotetext{
${ }^{50}$ Бауман Зигмунт. Индивидуализированное общество / Пер. с англ. под ред. В. Л. Иноземцева. Москва: Логос, 2002. С. 81.

51 Шемшученко Ю. С. Теоретические проблемы гармонизации законодательства Украины с европейским правом / Проблемы гармонизации законодательства Украины и стран Европы / Под общ. ред. Е. Б. Кубко, В. В. Цветкова. Киев: Юринком Интер, 2003. С. 35-40.
} 
primarily, the technical and legal improvement of the activities of legislative institutes ${ }^{52}$; e) humanization of legislation as the decriminalization of economic crimes, which stipulates the need to clarify the organizational and legal preconditions for the introduction of probation as a means of humanization of criminal justice, the formation, in particular, of the probation service - a system of supervision, social, educational and preventive measures of the approximation to the norms of European justice by replacing criminal liability with administrative one for certain types of crimes in economic and business activities. At least, in European countries, the probation service, as is known, significantly facilitates the work of law enforcement agencies, the judicial system, ensures the coordination of the interaction of state institutions, local governments, non-governmental organizations, individual citizens (volunteers) in the process of enforcing sentences alternative to deprivation of liberty ${ }^{53}$.

Interesting and largely ignored methods of teaching humanities at higher school are represented by the European experience with regard to ensuring the internal security of the state through means of probation.

At the same time, in the process of teaching legal disciplines, it should be emphasized that, the first of the aforementioned meanings of the term corresponds to the content of the term "humanization of legislation" best of all, while other definitions reflect, rather, the content of the legal categories "approximation" and "harmonization", although with varying degrees of completeness . It is advisable, of course, to rely on the norms of international law as a generally accepted standard of regulation of interstate relations. At the same time, it is hardly possible to agree with the assertions that the integration processes in the field of law are deployed as: a) the technical and legal harmonization of legislation (through methods of creating specific legal mechanisms of the interaction of legal systems); and b) direct approximation of Ukraine to European principles, ideals of democracy, the protection of human and civil rights ${ }^{54}$.

Philosophy-centrism with its human and nature correspondence, techno-informational and technological and innovation support as a sign of the unity of science and education, the continuity of mastering and

\footnotetext{
52 Кубко Е. Б. Совершенствование законодательства Украины и проблемы его гармонизации с законодательством зарубежных стран / Проблемы гармонизации законодательства Украины и стран Европы / Под общ. ред. Е. Б. Кубко, В. В. Цветкова. Киев: Юринком Интер, 2003. С. 61-78.

53 Кулик О. Г. Пробація // Юридична енциклопедія: В 6 т. / Редкол.: Ю. С. Шемшученко (голова редкол.) та ін. Т. 5. Київ: «Укр. енцикл.», 2003. С. 146-147.

${ }^{54}$ Политико-правовые и конституционно-правовые аспекты гармонизации законодательства Украины и стран Европы / Проблемы гармонизации законодательства Украины и стран Европы / Под общ. ред. Е. Б. Кубко, В. В. Цветкова. Киев: Юринком Интер, 2003. С. 97.
} 
reproduction of knowledge, its enrichment and development, harmony of education of a person and his humanistic self-realization is the theoretical and methodological basis of the methods of teaching humanities, a peculiar worldview core of didactic transformation of the content of science.

So what kind of value system can claim to be the universal, all-planet educational ideology or, say, the European one as its subsystem? First of all, it may obviously be represented by philosophical-ideological principles aimed at forming the essence of man as a representative of earthly civilization, its culture, the achievements of the humanity, etc, which (the principles) are in harmony with a separate personality, society, nature and space. And this means that the ideological foundations of the contemporary worldview of multicultural education should be complemented by anthropocosmic principles of conformity to nature, coherence of social development with evolutionary, elemental in nature, processes occurring in nature and space. That is, using the terminology of V. I. Vernadsky, our contemporary needs a noosphere type of worldview $^{55}$, which is based on the understanding of man as a natural, social and cosmic being, the rights and freedoms of man and citizen as natural and inalienable. Modern world humanistics proceeds from the fact that just a person, his rights and duties, demands and needs should be at the center of the attention of the state and society, and all social space is humanized, full of humanistic meaning, according to which a person, his life is the highest value, which, accordingly, involves the need to create appropriate conditions as the basic and determinant at the same time for full life, for self-realization of an individual. It seems that the aforementioned, in Ukrainian realities, involves, first of all, the possibilities of self-organization and self-governance, of decentralization of power in accordance with the constitutional requirements of the rule of law, of the establishment of united territorial communities as subjects of sovereignty of the people. The implementation of these requirements by means of the educational process is, at the same time, the answer to the question under what conditions welfare and abundance start belonging to the people, form its creative, intellectual potential, the ability to conduct social changes and implement promising scenarios of civilization development ${ }^{56}$. In this context, the humanization of education must give the student knowledge about society and the person in it, nature and

${ }^{55}$ Вернадский В. И. Начало и вечность жизни / Сост., вступ. ст., коммент. М. С. Бастраковой, И. И. Мочалова, В. С. Неаполитанской. Москва: Сов. Россия, 1989. 704 с.

${ }^{56}$ Гавриленко І. М., Мельник П. В., Недюха М. П. Соціальний розвиток : навчальний посібник. Київ: Академія ДПС України, 2001. С. 424-484. 
space, the place and purpose of the individual, allows to instill in young people high humanistic qualities - humanity, dignity, critical thinking, culture of communication, to establish civilized cohabitation as normalcy. The humanization of education "works" for the future and a person in it as the creator of the conditions of his life, his eternity and uniqueness in nature, society and space. Accordingly, in its essence, the humanization of education is directed at the transformation of educational activity - in terms of content, forms and technologies of learning - in the continuous process of ensuring the integrity of the formation of the personality of a future specialist in the unity of the natural, social and cosmic components, the affirmation of the subjectivity of human existence.

The aforementioned orientation of the methods of teaching humanitarian disciplines in higher education envisages, in particular: a) the realization of human and civil rights and freedoms for qualitative educational services; b) ensuring the unity of science and education in the educational process; c) subordinating the educational process to the needs of providing dynamic social changes, of innovation and technological development by forming a unified knowledge production environment and implementing its results; d) participation in international co-operation in the field of education and science, including with regard to the legal and regulatory substantiation of the process of entering the world and European educational and scientific space.

The purpose of education with regard to finding answers to the challenges of sovereign development lies in its focus on the formation of an innovation and investment environment for social changes, the production of scientific and technological developments and inventions and their introduction through the unity of education, science and production. In this triune interaction, the decisive role belongs, of course, to science as "a planetary phenomenon" ${ }^{57}$, to the sphere of professional activity, to social institute and, on many grounds, to "geological force" ${ }^{58}$. It is no accident that V. I. Vernadsky, considering the humanistic nature of science, its decisive role in solving the problems of human life, considered science as a geological and historical power at the same time, able to change the life of both the biosphere and humanity ${ }^{59}$. Accordingly, science should be seen as a means, resource and potential of development, the basis of which is represented, of course, by the abilities of the human

${ }^{57}$ Вернадский В. И. Начало и вечность жизни / Сост., вступ. ст., коммент. М. С. Бастраковой, И. И. Мочалова, В. С. Неаполитанской. Москва: Сов. Россия, 1989. С. 131-155.

${ }^{58}$ Там же. С. $133,135$.

${ }^{59}$ Там же. С. 131. 
mind. The power of man, as well as his weakness, his self-sufficiency and limitation, self-organization and chaotic social conditions cannot be considered beyond his mind, which subordinates human actions to the goals defined by classical science (description, awareness, solution and prediction), non-classical one (the positioning of subject of social action) and post-non-classical one (the construction of social space).

The task of the higher school, its social purpose is seen in the theoretical and methodological and methodological and technological revision, adaptation of scientific knowledge in accordance with the goals of the educational process, in building the latter in accordance with the requirements of the defining principles of didactics - the availability of knowledge, its continuity, consistency and ensuring the system integrity of the process of the assimilation of scientific knowledge, etc. The problem is that this link between science and education is not unambiguous, linear, given the ambivalence of science, which implies the need for humanization of scientific knowledge by, in particular, mitigating the effect of threatening tendencies, one of which is, as is known, the pragmatization of science, the consequence of which is not only obtaining benefits, but also suffering significant losses, in particular, environmental ones. The safe environment of human existence also involves taking into account possible negative social consequences of the application of the results of certain scientific and technological achievements in practice; the notorious technogenic accident at the Chernobyl Nuclear Power Plant can serve as an example.

\section{CONCLUSIONS}

Education should provide satisfactory answers to the challenges of sovereign development, of the globalization era by means of didacticmethodological transformation of achievements of world and national science, its humanization: the conceptual foundations of state educational policy should ensure the unity of science and education by adapting the achievements of the former to the tasks and objectives of the educational process, ensuring it efficiency, availability, continuity, consistency, and systemacity. Accordingly, the methods of teaching should contribute to the disclosure of the content of the discipline as a system of scientific knowledge in its subordination to the process of finding the truth, positioning and constructing the social space in accordance with the priorities of the process of social change, the cosmization of science, the understanding of the modern historical age as contradictory and 
critical at the same time with regard to the formation of the noosphere type of thinking and social action. The above, in particular, implies: a) understanding the essence of man as a bio-socio-cosmic being; b) the formation of the noosphere type of thinking and of the corresponding identity of the student - civil, national, political one, etc; c) professional training a future specialist, obtaining by him the necessary qualification competence, his readiness for life in a globalized multicultural environment.

Given the close relationship between methods and methodology, the didactical revision of the content of science, the purpose and task of the study, it can be argued that the methods of teaching humanitarian disciplines in higher education should study the laws of self-movement of the content of the discipline, the forms of organization and of the innovation and technological provision of the educational process in accordance with the requirements of pedagogy and didactics, the content and functional characteristics of the paradigms of scientific knowledge, the priority of human and civil rights and freedoms, the challenges and threats of the globalization era in their subordination to the formation of a noosphere type of thinking.

The above definition of the subject of the methods of teaching humanities, although it reflects the main, essential aspect of the process of training and education, namely its content orientation, consistency and purposefulness, cannot be considered complete, exhaustive, let alone definitive. As it is known, teaching any humanitarian discipline at a higher school is a creative matter, to a certain extent an art that requires not only the consideration of the movement of the content of learning, of organizational forms and technologies for its ensuring, but also the clarification of their relationship with each other with regard to, in particular, the most effective way of communicating the contents of learning to the consciousness of students, the acquisition of knowledge, critical attitude toward it, etc. The above envisages taking into account the specifics of the institution of higher education, the department, the audience, the knowledge already received by the students previously, ascertaining which sections of the course or its individual propositions to lay out in lectures or to make the subject of discussion at seminars, to give to the students for independent study, etc. Therefore, it is quite right to note that the methods of teaching humanities should study the correlation between the laws of motion (self-organization) of the content of the discipline being studied, organizational forms and modern technologies 
of ensuring the educational process, which (correlation) manifests itself in the most effective means of communicating the content of training to the students' consciousness, the formation of a noosphere type of thinking and action. In this case, the methods of teaching humanitarian disciplines in accordance with its above-mentioned subject facilitates the transformation of the educational process into a partner dialogue between the teacher and the student, of course, with the preservation of the status and role functions of each of them.

\section{SUMMARY}

The analysis of the correlation of a science and the academic discipline, of the functional unity of the content, forms and technologies of learning in the conditions of the use in the educational process of the classical, non-classical and post-non-classical paradigms of scientific knowledge allows to substantiate the subject of the methods of teaching humanities in higher education in accordance with the multicultural model of the educational process and the tasks of the formation of a noosphere type of thinking and action. Defining the content of the subject of the methods of teaching humanities at the higher school of Ukraine should facilitate the gradual transition of the educational process from the predominantly multi-ethnic coverage of the content of education to understanding it as a multicultural, intercultural and intergroup environment of interaction between the teacher and the students, forming a culture of tolerance, critical thinking, avoiding manifestations of discrimination, ethnocentrism and assimilation, etc. Professional competence as a decisive feature of the quality of the educational process should involve the unity of the content, goals and methodological and technological support of the educational process. The said implies the expediency of developing the problems of content filling of humanitarian disciplines, defining their place, structure, interdisciplinary connections, and also the normative and legal provision of teaching humanities in accordance with the basic propositions of the multicultural model of education, the formation of a noosphere type of thinking of a future specialist. Accordingly, the subject of the methods of teaching humanities at a higher school, due to the current state of development of science, requires didactic and pedagogical revision of its content by clarifying the effect of the latest trends of exponential growth of scientific knowledge and its use in the educational process, its results and social consequences, in particular: a) understanding the essence of man as a bio-socio-cosmic 
being; b) the content and nature of the cosmization of scientific knowledge, the transformation of science into a phenomenon of a planetary scale that acquires features of a geological force; c) the possibilities of a new synthesis of the natural and human sciences, laws of nature and space, society and man in a globalized multicultural space. It seems that the above will contribute to the crystallization of the subject of the methods of teaching humanitarian disciplines in higher education in its dependence on open potential and meaning benchmarks for the formation of a noosphere type of thinking within the framework of the multicultural model of education.

\section{REFERENCES}

1. Bennett C. I. Comprehensive multicultural education: Theory and practice / C.I. Bennett. Boston: Allyn \& Bacon, 1999. - 345 p.

2. Banks J. A. Multicultural Education: Characteristics and Goals / J. A. Banks // Multicultural Education: Issues and Perspectives. Wileys \& Sons, 2003. - P. 3-31.

3. Hелеп A. T. Теоретические проблемы методики преподавания философии. Киев: «Вища школа», 1973. - 291 с.

4. Мойсеюк Н. Є. Педагогіка : навчальний посібник. Вид. п’яте, доп. і перероб. Київ: ВАТ «Білоцерківська книжкова фабрика», 2007. $656 \mathrm{c}$.

5. Андрущенко Т.В. Ціннісний дискурс цивілізацій: монографія. Київ: Університет «Україна», 2011. - 440 с.

6. Дмитренко М. А. Наука і освіта як невід'ємна складова механізму реалізації стратегій інноваційного розвитку суспільства // Науковий часопис НПУ імені М. П. Драгоманова. Серія 22. Політичні науки та методика викладання соціально-політичних дисциплін. 2009. Випуск 2. - С. 24-33

7. Недюха М. П. Критика як теоретико-пізнавальний та діалоговополемічний конструкт конституційно-правового мислення // II Bceукраїнські правові наукові читання пам'яті доктора юридичних наук, професора, заслуженого юриста України, член-кореспондента Національної академії правових наук України Ніни Романівни Нижник: збірник матеріалів / за заг. ред. А. С. Шевченка. Вінниця: ТОВ «ТВОРИ», 2018. 180 с. - С. 94-98.

8. Бех В. П., Бех Ю. В. У пошуках нової парадигми освіти // Нова парадигма. Філософія. Політологія. Соціологія / Нац. пед. ун-т імені М. П. Драгоманова. Київ: Вид-во НПУ імені М. П. Драгоманова, 2014. Вип. 123. - С. 19-32. 
9. Мельниченко О. П. Основні методи та форми навчання в сучасній вищій школі // Науковий часопис Національного педагоггічного університету імені М. П. Драгоманова. Серія 5. Педагогічні науки: реалії та перспективи. Випуск 27. 2011. - С. 176-180.

10. Кліпа Ю. В. Сучасні основи навчання студентів засобами оnline в вищій школі // Нові концепції викладання у світлі інноваційних досягнень європейської дидактики вищої школи : матеріали міжн. наук.-метод. конф., 30-31 жовтня 2017 р. / Укл. С. М. Іваненко та ін. Київ: Вид-во НПУ імені М.П. Драгоманова, 2017. - С. 260-262.

11. Булда А. А. Електронний підручник в системі сучасних засобів навчання // Науковий часопис Національного педагогічного університету імені М. П. Драгоманова. Серія 22. Політичні науки та методика викладання соціально-політичних дисциплін : зб. наук. праць. Київ: Вид-во НПУ імені М. П. Драгоманова, 2009. Випуск 1. C. $18-21$.

12. Горбунова Людмила, Зглінська Наталія, Пролеєв Сергій та ін. Трансгуманітарність як чинник розвитку сучасної науки і освіти // Філософія освіти: наук. часопис. 2011. № 1-2. / Ін-т вищої освіти АПН України, Нац. пед. ун-т імені М. П. Драгоманова, Укр. академія політичних наук. Київ: Вид-во НПУ імені М.П. Драгоманова, 2011. C. $97-141$.

13. Червона Л. М. Принцип модернізації вітчизняної вищої освіти: академізм vs прагматизм // URL: journals.uran.ua/index.php/ 2312-1947/article/.../25971.

14. Тараненко Г. Г. Свроінтеграційні перспективи України на сучасному етапі // Науковий часопис Національного педагогічного університету імені М. П. Драгоманова. Серія 22. Політичні науки та методика викладання соціально-політичних дисциплін: зб. наук. праць. Випуск 21. Київ: Вид-во НПУ імені М. П. Драгоманова, 2017. C. $95-100$.

15. Скотна Надія. Філософська проблема особистості в цивілізаційному вимірі // Молодь і ринок. Дрогобич : 2015. № 3 (122). C. 6-14.

16. Морозов В. В. Фундаментальні цінності як засада організації освіти в європейському просторі // Науковий часопис Національного педагогічного університету імені М. П. Драгоманова. Серія 7: Релігієзнавство. Культурологія. Філософія / ред. рада: В. П. Андрущенко (голова). Вип. 29 (41). Київ: Вид-во НПУ імені М. П. Драгоманова, 2013. - С. 263-272. 
17. Литвиненко Т. С. Філософія виховання у трансформаційному освітньому просторі // Науковий часопис Національного педагогічного університету імені М. П. Драгоманова. Серія 7: Релігієзнавство. Культурологія. Філософія / ред. рада: В. П. Андрущенко (голова). Вип. 37 (50). Київ: Вид-во НПУ імені М. П. Драгоманова, 2017. - С. 76-84.

18. Гавриленко І. М., Мельник П. В., Недюха М. П. Соціальний розвиток : навчальний посібник. Київ: Академія ДПС України, $2001.484 \mathrm{c}$.

19. Терепищий С. О. Філософська парадигма сучасних освітніх ландшафтів : автореферат дис. ... докт. філос. наук : 09.00.10 / Мво освіти і науки України, Нац. пед. ун-т ім. М. П. Драгоманова. Київ, 2016. 34 с.

20. Синергетика в образовании : возможности методологии (круглый стол в редакции журнала «Філософія освіти» / Філософія освіти. Philosophy of Education: науковий журнал. 2006. № 3(5) // Ін-т вищої освіти НАПН України, Нац. пед. ун-т імені М. П. Драгоманова, 2006. - С. 54-91.

21. Регейло I. Ю. Тенденції підготовки наукових i науковопедагогічних кадрів вищої кваліфікації в Україні у XX - на початку XXI століття : автореферат дис. ... докт. пед. наук : 13.00 .04 / М-во освіти і науки України, Нац. пед. ун-т імені М. П. Драгоманова. Київ: 2015. 39 с.

22. Чижова О. М. Стратегія трансформації української освіти в контексті розуміння прагматизму // Науковий часопис Національного педагогічного університету імені М. П. Драгоманова. Серія 22: Політичні науки та методика викладання соціально-політичних дисциплін : зб. наук. праць. Випуск 15. Київ: Вид-во НПУ імені М. П. Драгоманова, 2014. - С. 190-195.

23. Без’язичний Б. І., Журід С. М., Худякова В. Б., Шаленко В. В. Технологічний підхід до освітнього процесу у ВНЗ // Науковий часопис Національного педагогічного університету імені М. П. Драгоманова. Серія 15. Випуск 5 (87). Київ: Вид-во НПУ імені М. П. Драгоманова, 2017. С. 9-12.

24. Концептуальні засади розвитку педагогічної освіти в Україні та iii інтеграції в європейський освітній простір // URL: www.mon.gov.ua/ images/education.

25. Клепко С. Ф. Автономія університету і міждисциплінарна інтеграція // Магістратура: історія становлення, перспективи розвитку: 
матеріали регіональної наук. - практ. конф., 21 квітня 2004 р. / Полтавський державний педагогічний університет імені В. Г. Короленка, Полтавський обласний інститут післядипломної педагогічної освіти імені М. В. Остроградського. Полтава: АСМI, 2004. C. 40-44.

26. Кремень В.Г. Проблеми якості української освіти в контексті сучасних цивілізаційних змін // Європейські педагогічні студії / Асоціація ректорів педагогічних університетів Європи; ред. кол. В. П. Андрущенко (голова) [та ін.]. Вип. 5-6. Київ: Вид-во НПУ імені М. П. Драгоманова, 2015. - С. 12-21.

27. Подоляка С. А. Теоретико-практичні основи адміністративно-правового забезпечення протидії корупції в органах прокуратури України : монографія. Київ: «Людмила», 2018. 440 с.

28. Перепелиця Г. М. Україна - Росія: війна в умовах співіснування. Київ: Видавничий дім «Стилос», 2015. 880 с.

29. Горбунова Людмила. Транскультурна освітня стратегія в контексті викликів глобалізації // Філософія освіти. Philosophy of Education : науковий журнал. 2014. № 1 (14) / Ін-т вищої освіти НАПН України, Нац. пед. ун-т імені М. П. Драгоманова, 2014. C. $158-198$.

30. Шевель Н.О. Формування української національної ідентичності в умовах глобалізації освіти // Науковий часопис НПУ імені М. П. Драгоманова. Серія 22. Політичні науки та методика викладання соціально-політичних дисциплін : [збірник наукових праць]. Київ: Видавництво НПУ імені М.П. Драгоманова, 2014. Спецвипуск : Політика і духовність в умовах глобальних викликів : матеріали Міжнар. наук.-практ. конференції, 2-3 квітня 2014 р. C. 338-342.

31. Горбунова Людмила. Транскультурна компетентність: освітній шлях до глобальної культури миру // Філософія освіти. Philosophy of Education : науковий журнал. 2014. № 2 (15) / Ін-т вищої освіти НАПН України, Нац. пед. ун-т імені М.П. Драгоманова, 2014. - С. 141-167.

32. Тимченко Л. А., Тимченко Л. Д. Международное право : практикум. Ирпень: Академия ГНС Украины, 2002. 290 с.

33. Штобрин Славомір. Становище філософії освіти в Польщі в кінці XX - на початку XXI століття // Філософія освіти. Philosophy of Education : науковий журнал. 2015. № 1 (16) / Ін-т вищої освіти НАПН України, Нац. пед. ун-т імені М.П. Драгоманова, 2015. C. $140-156$. 
34. Banks J. A. Cultural Diversity and Education: Foundations, Curriculum and Teaching . - 2014. (6 ${ }^{\text {th }}$ ed.). Boston: Allyn \& Bacon. $384 \mathrm{pp}$.

35. Кляп М. І. Підвищення педагогічної майстерності викладача ВН3 у контексті інтернаціоналізації вищої школи України // Науковий часопис Національного педагогічного університету імені М. П. Драгоманова. Серія 16 : збірник наукових праць. Вип. 25 (35). Київ: Вид-во НПУ імені М.П. Драгоманова, 2015. - С. 47-52.

36. Біляєва I. І. Медіа-освіта як ціннісно-культурний компонент трансформації сучасного суспільства // Науковий часопис НПУ імені М. П. Драгоманова. Серія 22. Політичні науки та методика викладання соціально-політичних дисциплін : [збірник наукових праць]. Київ: Видавництво НПУ імені М.П. Драгоманова, 2014. Спецвипуск : Політика і духовність в умовах глобальних викликів : матеріали Міжнар. наук.-практ. конференції, 2-3 квітня 2014 р. C. 280-288.

37. Якуба О. О. Соціологія. Харків: «Фоліо», 1996. 337 с.

38. Сорокин П. А. Общедоступный учебник социологии. Статьи разных лет / Ин-т социологии. Москва: Наука, 1994. 560 с.

39. Каньковський Ігор. Принципи професійного навчання фахівців у сучасній вищій школі // Молодь і ринок. Дрогобич : 2015. №12 (131). C. 15-22.

40. Jefferson N. Migrant Report Office - Multicultural Education, US Dpt of Education, April, 2002. P. 16-24.

41. Горак Оксана. Філософія гуманізму. Становлення та розвиток гуманістичної парадигми освіти // Молодь і ринок. Дрогобич, 2015. № 11 (130). С. 147-150.

42. Бех В. П. Философская рефлексия предмета политологии // Вопросы политологии. 2016. № 2 (22). С. 7-16.

43. Лакомчак Зоряна. Дидактичний потенціал сучасної інтернетдидактики // Молодь і ринок. Дрогобич : 2015. № 8 (127). С. 121-124.

44. Васиньова Н.С. Розвиток теорії управління вищими навчальними закладами в Україні (остання чверть XX - початок XXI століття). Дисертація на здобуття наук. ступ. канд. пед. наук за спеціальністю 13.00.06 / М-во освіти і науки України, Луганський національний університет імені Тараса Шевченка. Старобільськ : 2019. - 294 c.

45. Bakhov I. S. Historical dimension to the formation of multicultural education of Canada. Pedagogika. 2015. Vol. 117, Issue 1. P. 7-15. 
46. Недюха М. П. Критика як поняття класичної науки та соціальний феномен громадянського суспільства: потенціал конституційного та міжнародного права // Критичне мислення у вільному суспільстві: теоретико-методологічний, конституційно- та міжнародно-правовий потенціал: Матеріали міжнародної науково-практичної конференції, м. Київ, 17 квітня 2019 р. Київ: Таврійський національний університет імені В. І. Вернадського, 2019. 156 с.

47. Бауман Зигмунт. Индивидуализированное общество / Пер. с англ. под ред. В. Л. Иноземцева. Москва: Логос, 2002. 390 с.

48. Шемшученко Ю. С. Теоретические проблемы гармонизации законодательства Украины с европейским правом / Проблемы гармонизации законодательства Украины и стран Европы / Под общ. ред. Е. Б. Кубко, В. В. Цветкова. Киев: Юринком Интер, 2003. С. 35-40.

49. Кубко Е. Б. Совершенствование законодательства Украины и проблемы его гармонизации с законодательством зарубежных стран / Проблемы гармонизации законодательства Украины и стран Европы / Под общ. ред. Е. Б. Кубко, В. В. Цветкова. Киев: Юринком Интер, 2003. С. 61-78.

50. Кулик О. Г. Пробація // Юридична енциклопедія: В 6 т. / Редкол.: Ю. С. Шемшученко (голова редкол.) та ін. Т. 5. Київ: «Укр. енцикл.», 2003. 736 с.

51. Политико-правовые и конституционно-правовые аспекты гармонизации законодательства Украины и стран Европы / Проблемы гармонизации законодательства Украины и стран Европы / Под общ. ред. Е. Б. Кубко, В. В. Цветкова. Киев: Юринком Интер, 2003. С. 97.

52. Вернадский В. И. Начало и вечность жизни / Сост., вступ. ст., коммент. М.С. Бастраковой, И. И. Мочалова, В. С. Неаполитанской. Москва: Сов. Россия, 1989. 704 с.

\section{Information about the author:}

Nediukha M. P.

Doctor of Philosophic Sciences, Doctor of Law, Professor, Professor at the Department of Constitutional and International Law of the V. I. Vernadsky Taurida National University 33, Ivan Kudria str., Kyiv, Ukraine nngi@tnu.edu.ua 